\title{
HOUSEHOLD DEBT AND COUNTRY ECONOMIC GROWTH: DOES A MAGIC THRESHOLD EXIST?
}

\author{
Siti Nurazira Mohd Daud* \\ Universiti Utara Malaysia \\ Jan M Podivinsky \\ University of Southampton \\ Khairunnisa Abd Samad \\ Universiti Teknologi MARA Melaka
}

\begin{abstract}
Average household debt has now surpassed the level of 2008, which signals an increase in systemic risk and thereby the fragility of the financial system. This paper investigates the effect of household debt on 24 countries' economic growth. In addition, we also examine whether a tipping point of debt exists. By employing the threshold method, we found that the impact of household debt on a country's economic growth is negative. Because the relationship between debt and growth is a monotonically non-increasing function, we do not find a magic threshold of debt.
\end{abstract}

Keywords: household debt, economic growth, threshold, tipping-point, developed and developing countries, crisis

Received: 21 March 2019

Accepted: 29 July 2020

https://doi.org/10.33736/ijbs.3160.2021

\section{INTRODUCTION}

The life-cycle theory of consumption and permanent income hypothesis postulates that households smooth their consumption by borrowing. Although the literature on consumption smoothing is well established, theoretical, and empirical work on household overindebtedness is still limited. However, the subprime mortgage crisis that began in the United States warned economists about the danger of high household indebtedness because of the cost incurred in the event of an economic recession. ${ }^{1}$ Since then, a great deal of research has been conducted focused on diagnosing the cause and effect of household debt before linking it to the probability that a crisis will break out.

\footnotetext{
- Corresponding author: Siti Nurazira Mohd Daud, School of Economics, Finance and Banking, College of Business, Universiti Utara Malaysia, 06010 Sintok, Kedah, Malaysia, Phone:+604 928 6831, email: sitinurazira@uum.edu.my

${ }^{1}$ Upward deviations of credit from the steady state and high repayment often lead to an increase in macroeconomic imbalance as well as a greater probability of banking crises (Rubaszek \& Serwa, 2014).
} 
Recent developments in developed and emerging economies show a high and rising pattern of household indebtedness, with signs of a credit and housing boom detected in several studies (Chen \& Kang 2018; Daud, Ahmad \& Podivinsky, 2017; Fielding \& Rewilak 2015; Schularick \& Taylor 2012). According to the Global Financial Stability report from the International Monetary Fund (IMF) in 2017 (IMF, 2017), since 2008, the median debt ratio in advanced economies rose from 52 percent of the gross domestic product (GDP) in 2008 to 63 percent in 2016, and the ratio in emerging economies increased from 15 percent to 21 percent. Furthermore, the household debt to GDP expanded rapidly over a short time and is far exceeding the growth of real GDP and real disposable income (IMF, 2017). These high credit growth and credit to GDP levels signal a greater risk to growth, thus highlighting the urgency of investigating this issue. ${ }^{2}$ Canada, the United Kingdom, the United States, Australia, Malaysia, and Thailand are among the countries that have accumulated high household indebtedness and have become the main concern in the world economy. In addition, it is notable that high household debt can be a source of financial vulnerability and stability (Mian \& Sufi, 2011). However, there is no specific level of debt classification or threshold that has been imposed by the IMF or other related organizations. Furthermore, one question arises: does a magic threshold exist? ${ }^{3}$ Policy makers could benefit by having an answer to this question. Although quite a number of studies have been conducted to investigate the role of household debt on economic growth (Alter, Feng, \& Valckx, 2018; Mian, Sufi, \& Emil, 2017; Dynan \& Edelberg, 2013), far too little attention has been given to identifying the possible optimal level household debt level. This scenario has underlined the motivation of this paper.

This paper aims to investigate the possible non-linear effect of household debt and economic growth, where the threshold level is examined. This paper sheds light on this debatable issue by investigating the effect of the household debt-growth nexus in countries with debt to GDP ratios exceeding 50 percent (as of the end of 2016) on the prediction of a threshold level from one that is endogenously determined, depending on the country's growth. Since there is no debt classification by the IMF or any related organization, as a point of departure, we initiate this study by selecting countries that hold household debt as percent of GDP equals to or exceeds 50 percent as at the end of 2016. This is based on the assumption that where the debt to GDP exceed 50 percent, this is associated with high-risk economy. This research is particularly relevant with a current scenario in leveraging economy. The paper is structured as follows. The next section provides an overview of the literature. Section 3 reviews the data and methodology, the empirical results are presented in section 4, and section 5 concludes the paper.

\section{LITERATURE REVIEW}

The impact of household debt on country economic growth has attracted considerable interest among researchers in the past few years. There is existing literature on theoretical and empirical

\footnotetext{
${ }^{2}$ Recent, Global Financial Stability Report: Lower for Longer published by IMF in 2019, highlights the financial vulnerability of the household sector continue to be elevated in China and other advanced economies (consisting of Australia, Canada, Denmark, Hong Kong SAR, Japan, Korea, Norway, Singapore, Sweden, Switzerland, and the United Kingdom) which highlight the relevancy and the importance of this issue to be monitored closely. In addition, the financial vulnerability indices (FVIs) are using the growthat-risk $(\mathrm{GaR})$ specification are constructed as a credit-weighted aggregate of household.

${ }^{3}$ The "magic" threshold is the tipping point or optimal level of household debt that a country should hold.
} 
research, centered within the effect of debt in particular to government debt and external debt on country economic growth (Daud \& Podivinsky, 2011, 2014). However, studies on the linkages between household debt and economic growth are relatively scarce, but gaining importance, nevertheless. Theoretically, households borrow to fund their consumption (Ando \& Modigliani, 1963). In addition, temporary income shocks may also contribute to the borrowing activity for consumption smoothing and investment in non-financial assets (Mian, Sufi, \& Verner, 2015; Friedman, 1957). On the other hand, households also acquire debt for the purpose of asset accumulation (Jappelli, Panago, \& Di Maggio, 2013; Mian \& Sufi, 2009), and debt accumulation is also motivated by a household's intention to undertake investment for their children for financial security purposes (Friedline \& Song, 2013). ${ }^{4}$ As such, the links between the consumer expenditure theory of Ando and Modigliani (1963) and economic growth lies between the effect of balancesheet on aggregate demand. Debt would help households to smooth shocks and raise consumption, aggregate demand and country economic growth via the mobilization of capital (investment opportunities) as a source of economic growth. Thus, explaining the relationship of debt may be associated with GDP growth. Furthermore, during the Great Depression, the household balancesheet could be linked to economic contraction (Mishkin,1978). This is harmonized with the idea of financial development-led growth where evidence on the effect of financial development on economic growth are relatively vast and emerged into consensus that it improves growth (Benhabib \& Spiegel, 2000; Christopoulos, \& Tsionas, 2004; Levine, 2005; Levine, 1997; Hassan, Sanchez \& Yu, 2011; Liang \& Teng, 2006). Later, Law and Singh (2014) and Law, Azman-Saini, and Ibrahim (2013) found that the impact of financial development should only be leveraging up to certain level where the institutional quality plays a major role in moderating the effect of financial development on growth. However, high levels of household debt are possibly harming growth in the case where aggregate consumption and output shrink due high debt service burden.

There are limited studies that analyze the impact of household debt to real economic activity (Dynan \& Edelberg, 2013; Dynan, 2012; Cooper, 2012; Mian et al., 2017; Mian, Rao, \& Sufi, 2013). By employing data from the Panel Study of Income Dynamics (PSID), Dynan (2012) and Cooper (2012) found that household debt affect consumption. Furthermore, Mian et al., 2013 conducted a related consumption analysis and found that the marginal propensity to consume was higher among household with high leverage. Because the finding in literature is skewed toward the negative effect of household debt on consumption and growth (Alter et al., 2018; Mian et al., 2017; Dynan \& Edelberg, 2013) and debt as a predictor and determinant of financial crisis (Alter et al., 2018; Schularick \& Taylor 2012; Jorda, Schulauck, \& Taylor, 2013, 2016; Mian \& Sufi, 2010), research dynamism in this area is aimed to find the optimal level of household debt. However, to date, few studies examine this issue (Lombardi, Mohanty, \& Shim, 2017; Ntsalaze \& Ikhide, 2017), leaving room for a different dimension of study to be conducted. By means of a simple dummy that sets a certain threshold level, Lombardi et al., (2017) find that household debt at 60 percent and 80 percent (of GDP) lower consumption and growth respectively for a pool of countries, whereas Ntsalaze and Ikhide (2017) identify a tipping point of 42.5 percent of household debt to disposable income. With limited and inconclusive findings on the tipping point of household debt, this paper focuses on the possible tipping point that may exist, and therefore our paper fills in the gap in the literature.

\footnotetext{
${ }^{4}$ While recent micro studies by Nakajima (2020) on the Japanese economy highlight that the income elasticity is higher for households with higher debt levels which indicates precautionary saving motives play an important role in household decisions to borrow.
} 


\section{METHODOLOGY}

To develop the threshold model on the debt-growth nexus, we use the economic growth model:

$$
\mathrm{GROWTH}_{t}=\beta^{\prime} \mathrm{HHDEBT}_{t}+\gamma X_{t}+\varepsilon_{t}
$$

where GROWTH $H_{t}$ measures country economic growth (real GDP per capita growth) at time $t$, $H H D E B T_{t}$ is household debt; measured as the growth rate of household debt (in US dollars) and the lagged $(t-1)$ household debt to GDP ratio, $\mathrm{X}$ is a vector of controls (lagged income level, population growth, and the investment ratio, which represent the rates of growth of factor inputs in the production function and trade openness; represent country-specific policy), and $\varepsilon_{t}$ is a noise term. To identify the possibility of non-linear relationship between the household debt on economic growth, we first estimate:

$$
\begin{aligned}
\text { GROWTH }_{t}= & \beta_{0}+\beta_{1} \text { INITIAL INCOME }_{t-1}+\beta_{2} \text { HHDEBT }_{t}+\beta_{3} \text { HHDEBT }_{t}^{2}+ \\
& \beta_{4} \text { INVESTMENT }_{t}+\beta_{5} \text { POPULATION }_{t}+\beta_{6} \text { TRADE }_{t}+\varepsilon_{t}
\end{aligned}
$$

By applying the quadratic function, we are imposing a priori restriction that the effect would monotonically symmetrically increase and decrease with the level of household debt. However, it could be the other way around, where a country needs to achieve a certain level of household debt before it can benefit the country's economic growth. Therefore, given this discrepancy, we adapt the threshold regression approach by Hansen (2000) to explore the nonlinear behavior of debt in relation to economic growth as follows:

$$
\begin{aligned}
\text { GROWTH }_{t}= & \left(\beta_{1} \text {HHDEBT }_{t}+\gamma_{1} X_{t}\right) I(\text { HHDEBTL } \leq \lambda)+ \\
& \left(\beta_{2} H H D E B T+\gamma_{2} X_{t}\right) I(H H D E B T L \geq \lambda)+\varepsilon_{t}
\end{aligned}
$$

where HHDEBTL (household debt as percentage of GDP at time $t$ ) is the threshold variable, and $\lambda$ is the unknown threshold parameter, and I(.) is the indicator function, which takes value a of 1 if the argument is valid, and 0 otherwise. This allows the role of household debt on growth to differ, depending on whether the household debt as percentage of GDP is below or above some unknown level. The impact of debt growth on a country's economic growth are captured by $\beta_{1}$ and $\beta_{2}$ for low and high regimes respectively. If $\beta_{1}=\beta_{2}$, the model becomes linear and reduces to Equation (1). The first step is to test the null of linearity $H_{o}=\beta_{1}=\beta_{2}$, against the threshold model in Equation (3). Inferences (based on bootstrapping) were implemented by calculating a Wald test for each possible value of $\lambda$ and subsequently basing inferences on the supremum Wald across all possible $\lambda s$, which were obtained by minimizing the residual, the sum of the squares computed across all possible values of $\lambda$, to obtain estimates of the slope parameter. ${ }^{5}$

In addition, an endogenous Chow-structural test (Diallo, 2012) is performed for household debt level to detect the presence of structural break-points. ${ }^{6}$ The advantage of test is that it does not

\footnotetext{
${ }^{5}$ One of the limitations of the Hansen (2000) is that, it could not take into consideration the dummy variable.

${ }^{6}$ The null hypothesis is the non-existence of a structural change in our model.
} 
require to provide an exogenous point where we suspect a structural change exist. In addition, this test could define the existence of successive thresholds. Data are collected from the World Development Indicator (WDI) from the World Bank (WB) database and the Bank for International Settlements (BIS). ${ }^{7}$ Our sample includes countries listed by the International Monetary Fund (IMF) where the debt to GDP ratio (as of the end of 2016) exceeds 50 percent, which indicates a highrisk economy. ${ }^{8}$

\section{RESULTS AND DISCUSSION}

Figure 1 plots average growth of GDP per capita and household debt in 24 countries. Descriptively, the mean growth of GDP per capita is lower than the growth of household debt, at 0.595 and 1.233 percent respectively, which highlights the potential risk to macroeconomics and financial stability. Based on the average data from 2008 to 2016, Singapore, Thailand, Hong Kong and Korea were among countries that experience household debt growth between 5 percent to 10 percent coupled with less than four percent GDP per capita growth. Greece, Portugal, Spain, and Denmark are experiencing negative growth in both GDP per capita and household debt. On the other hand, countries that experience negative growth in GDP per capita and positive growth in household debt, such as Luxembourg, Norway, and Finland, showed a worrying situation. As such, this highlights the need of empirical testing on the possible existence of a threshold level of household debt.

Figure 1: Household debt versus GDP per capita growth (average 2008-2016)

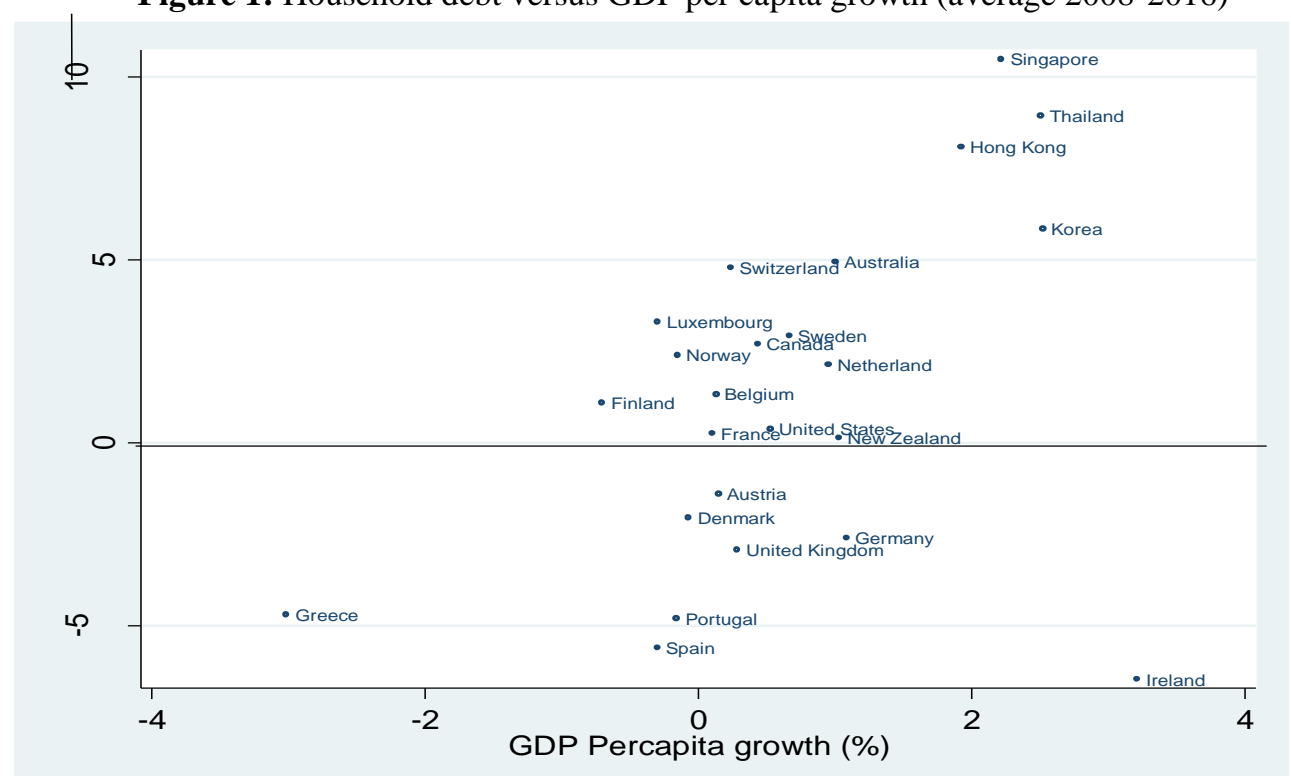

Note: $\mathrm{HH}$ debt denoted the household debt.

\footnotetext{
${ }^{7}$ The coverage of each sample, depending on data availability. Details on the source of data is available in Appendix 1.

${ }^{8}$ Since we only consider countries with household debt holding more than 50 percent of GDP, this would remain the limitation of our study.
} 
The empirical test starts with a preliminary test on the possibility of a non-linear relationship between household debt and a country's economic growth. The estimates are present in Table 1. By employing two proxies of household debt namely household debt growth and lagged of household debt to GDP ratio, the lagged of household debt to GDP ratio shows significant at level and quadratic term of household debt for Switzerland, Canada, United Kingdom and Sweden at least at 5 percent significance level. Thus, this indicates there is a possible non-linear relationship between household debt and economic growth. Even though, this might suggest the possible existence of a tipping-point of household debt variables on country growth. The square term would have some discrepancy in interpreting the effect on economic growth (Law \& Singh, 2014). Thus, this would serve as preliminary test of a non-linear relationship between household debt and economic growth before analysis on threshold model are conducted.

Table 1: Baseline analysis of the nonlinear relationship between household debt and economic growth.

\begin{tabular}{|c|c|c|c|c|c|}
\hline Country & $\begin{array}{l}\text { HHDEBT: } \\
\text { household debt } \\
\text { growth }\end{array}$ & $\begin{array}{c}\text { HHDEBT: } \\
\text { household debt } \\
\text { growth) }{ }^{\wedge}\end{array}$ & $\begin{array}{c}\text { HHDEBT: } \\
\text { Lagged } \\
\text { household debt } \\
\text { to GDP ratio }\end{array}$ & $\begin{array}{c}\text { (HHDEBT: } \\
\text { Lagged } \\
\text { household debt } \\
\text { to GDP ratio) } \\
\wedge 2\end{array}$ & Period \\
\hline Switzerland & $\begin{array}{l}-0.01(0.86) \\
\end{array}$ & $-0.00(0.78)$ & $3.85 *(0.00)$ & $-0.02 *(0.00)$ & $2000-2016$ \\
\hline Australia & $0.01(0.63)$ & $-0.00(0.76)$ & $-0.05(0.61)$ & $0.00(0.94)$ & 1978-2016 \\
\hline Denmark & $-0.05 * *(0.05)$ & $0.000(0.79)$ & $-0.22(0.24)$ & $0.00(0.21)$ & 1995-2016 \\
\hline Netherland & $-0.07(0.20)$ & $0.00(0.26)$ & $0.16(0.17)$ & $-0.00 * *(0.09)$ & 1991-2016 \\
\hline Norway & $0.01(0.83)$ & $-0.00(0.97)$ & $-0.02(0.92)$ & $0.00(0.99)$ & 1976-2016 \\
\hline Canada & $0.12 *(0.00)$ & $-0.00 *(0.01)$ & $-0.48 *(0.00)$ & $0.00 *(0.00)$ & 1970-2016 \\
\hline Korea & $0.05 *(0.01)$ & $0.00(0.50)$ & $-0.17(0.43)$ & $0.00(0.63)$ & 1969-2016 \\
\hline New & $0.33(0.22)$ & $-0.04(0.13)$ & $0.20(0.49)$ & $-0.00(0.44)$ & $1991-2016$ \\
\hline Zealand & & & & & \\
\hline $\begin{array}{l}\text { United } \\
\text { Kingdom }\end{array}$ & $0.04(0.21)$ & $-0.00(0.86)$ & $0.23 *(0.05)$ & $-0.00 *(0.03)$ & $1969-2016$ \\
\hline Sweden & $0.06(0.13)$ & $-0.00(0.100)$ & $-1.14 *(0.03)$ & $0.01 *(0.03)$ & 1981-2016 \\
\hline Thailand & $0.08(0.21)$ & $-0.00(0.71)$ & $-0.49(0.43)$ & $0.00(0.62)$ & 1992-2016 \\
\hline $\begin{array}{l}\text { United } \\
\text { States }\end{array}$ & $0.05(0.79)$ & $0.00(0.66)$ & $0.25(0.17)$ & $-0.00(0.13)$ & $1968-2016$ \\
\hline Portugal & $0.07 *(0.00)$ & $0.00(0.86)$ & $0.12(0.14)$ & $-0.00 *(0.04)$ & 1980-2016 \\
\hline Hong Kong & $-0.12(0.67)$ & $0.01(0.42)$ & $-0.57(0.53)$ & $0.00(0.61)$ & 1991-2016 \\
\hline Finland & $0.02(0.64)$ & $-0.00(0.52)$ & $-0.08(0.65)$ & $-0.00(0.83)$ & $1971-2016$ \\
\hline $\begin{array}{l}\text { Luxembour } \\
\mathrm{g}\end{array}$ & $-0.15(0.34)$ & $0.01(0.10)$ & $-3.48(0.43)$ & $0.03(0.41)$ & 2003-2016 \\
\hline Spain & $0.04(0.19)$ & $0.00(0.48)$ & $-0.20(0.18)$ & $0.00(0.51)$ & 1981-2016 \\
\hline Greece & $0.05(0.76)$ & $0.00(0.98)$ & $0.12(0.54)$ & $-0.00(0.19)$ & $1995-2016$ \\
\hline Belgium & $0.04(0.28)$ & $-0.00(0.76)$ & $-0.14(0.66)$ & $0.00(0.99)$ & $1981-2016$ \\
\hline Singapore & $0.08(0.56)$ & $0.00(0.34)$ & $-1.00(0.11)$ & $0.01(0.16)$ & $1992-2016$ \\
\hline France & $-0.01(0.84)$ & $0.00(0.75)$ & $0.09(0.56)$ & $-0.00(0.32)$ & 1978-2016 \\
\hline Germany & $-0.01(0.82)$ & $0.00(0.17)$ & $0.41(0.11)$ & $-0.00(0.13)$ & $1971-2016$ \\
\hline Ireland & $-0.30(0.36)$ & $0.01 *(0.05)$ & $0.30(0.71)$ & $-0.00(0.432)$ & $2003-2016$ \\
\hline Austria & $-0.00(0.94)$ & $0.00(0.31)$ & $-2.45(0.48)$ & $0.02(0.53)$ & $1996-2016$ \\
\hline
\end{tabular}

Notes: $*$ and $* *$ denotes significance at the 5 and 10 percent levels respectively. Values in parentheses are p-values. Classification of level of debt is based on IMF data at end of 2016. 
Table 2 shows the LM test results in determining the non-linearity relationship between household debt and economic growth. With 1,000 replications and a 15 percent trimming percentage, the null of linearity can be rejected for the household debt effect on economic growth in Switzerland, Australia, Norway, New Zealand, United Kingdom, Sweden, Portugal, Finland, Spain, Greece at the 5 percent significance level. Meanwhile, Germany, Ireland, and France are found to reject the null of linearity at 10 percent significance level. This indicates the non-linear relationship of the estimated model.

Table 2: Testing the nonlinear relationship between household debt and economic growth.

\begin{tabular}{ccc}
\hline \hline Country & \multicolumn{2}{c}{ LM test White corrected) } \\
\cline { 2 - 3 } & $\begin{array}{c}\text { HHDEBT: household debt } \\
\text { growth }\end{array}$ & $\begin{array}{c}\text { HHDB : Lagged household } \\
\text { debt to GDP ratio }\end{array}$ \\
\hline Switzerland & $11.26^{*}(0.01)$ & $11.33^{*}(0.02)$ \\
Australia & $13.88^{*}(0.01)$ & $8.61(0.44)$ \\
Denmark & $5.92(0.76)$ & $7.05(0.58)$ \\
Netherland & $10.07^{*}(0.08)$ & $9.79(0.20)$ \\
Norway & $8.42(0.40)$ & $14.74^{*}(0.02)$ \\
Canada & $16.78(0.10)$ & $11.22(0.10)$ \\
Korea & $10.03(0.13)$ & $10.50(0.12)$ \\
New Zealand & $8.25(0.42)$ & $11.37 *(0.02)$ \\
United Kingdom & $13.11^{*}(0.02)$ & $12.71 *(0.04)$ \\
Sweden & $12.66^{*}(0.02)$ & $10.14(0.12)$ \\
Thailand & $6.61(0.76)$ & $6.41(0.77)$ \\
United States & $10.47(0.18)$ & $9.31(0.37)$ \\
Portugal & $12.48^{*}(0.03)$ & $11.70^{* *}(0.09)$ \\
Hong Kong & $6.45(0.71)$ & $6.56(0.65)$ \\
Finland & $17.12^{*}(0.00)$ & $12.66^{*}(0.04)$ \\
Luxembourg & $8.50(0.15)$ & $8.53(0.16)$ \\
Spain & $12.45^{*}(0.04)$ & $14.77^{*}(0.00)$ \\
Greece & $12.62^{*}(0.01)$ & $9.46^{* *}(0.07)$ \\
Belgium & $9.49(0.22)$ & $6.53(0.79)$ \\
Singapore & $7.16(0.63)$ & $7.18(0.62)$ \\
France & $8.96(0.29)$ & $11.82^{* *}(0.06)$ \\
Germany & $11.76^{* *}(0.05)$ & $8.25(0.48)$ \\
Ireland & $9.21^{* *}(0.06)$ & $8.30(0.18)$ \\
Austria & $6.07(0.84)$ & $6.09(0.88)$ \\
\hline \hline
\end{tabular}

Notes: $*$ and ${ }^{* *}$ denotes significance at the 5 and 10 percent levels respectively. Values in parentheses are p-values.

In addition, it also implies that Australia, Norway, Sweden, New Zealand, Portugal and Greece are found to have a nonlinear effect of debt on growth, subject to the debt measurement used. As such, the estimations are sensitive to different proxies' debt used for the effect of household debt on country growth. Other control variable shows the correct signs and are significant at least at a 5 percent significance level. ${ }^{9}$ We then proceed to an in-depth analysis that is based on the significant debt measurement and the effect of debt on country growth are shown in Table 3 . The threshold estimates vary across countries from 25.1 percent to 110.6 percent, likely explained by countryspecific characteristics. There is evidence of a turning points or optimal level of household debt

\footnotetext{
${ }^{9}$ The results are available upon request.
} 
for France, where the effect of household debt is positive below the threshold level of 32.5 percent. Above the threshold level, the effect of household debt becomes negative to affect country economic growth. This implies that the threshold estimates should be treated as a tipping point for France.

However, the negative effect holds in most cases (below and above threshold). Looking from country-by-country view, an increase in growth rate of household debt of Switzerland, has insignificant effect on country economic growth below the threshold level. While an increase of household debt to GDP beyond the 110.6 percent debt to GDP show a negative effect at 5 percent significance level. In addition, estimates for New Zealand and Greece shows a similar pattern. In addition, United Kingdom, Portugal and Spain are among countries that are experiencing a negatively significant (at the 5 percent significance level) effect of household debt on country economic growth below and above the threshold, which indicates that the relationship is monotonic. Thus, the threshold estimates could not be treated as an optimal level or turning point of household debt holding for the United Kingdom, Portugal and Spain. This finding confirms the results of Alter et al., (2018), Mian et al., (2017), and Dynan and Edelberg, (2013) on the negative effect of household debt on the country's economic growth. Meanwhile, Finland is experiencing the negative effect of household debt on country growth below the threshold level. Besides the negative effect experienced by United Kingdom, Portugal, Spain and Finland, the effect of household debt on growth below the threshold level is positive and significant at 5 percent significance level for Sweden, Germany and Norway. Above the threshold level, the household debt is insignificant to affect country growth. In other words, Norway, Germany, Sweden and Portugal should hold their household debt below 67.9 percent, 50.8 percent, 48.0 percent and 58.8 percent threshold level where above the level, the effect become insignificant.

Table 3: The nonlinear effect of growth of household debt on country growth (using household debt as percentage of GDP as threshold variable)

\begin{tabular}{|c|c|c|c|c|c|c|c|}
\hline \multirow[t]{2}{*}{ Country } & \multirow{2}{*}{$\begin{array}{c}\text { Household } \\
\text { debt (\% of } \\
\text { GDP), } \\
2016\end{array}$} & \multicolumn{3}{|c|}{$\begin{array}{l}\text { Growth rate of household debt on } \\
\text { economic growth }\end{array}$} & \multicolumn{3}{|c|}{$\begin{array}{l}\text { Lagged household debt to GDP } \\
\text { ratio effect on economic growth }\end{array}$} \\
\hline & & $\begin{array}{l}\text { HHDEBTL } \\
\leq \lambda\end{array}$ & $\begin{array}{l}\text { HHDEBTL } \\
\geq \lambda\end{array}$ & $\lambda$ & $\begin{array}{l}\text { HHDEBTL } \\
\leq \lambda\end{array}$ & $\begin{array}{l}\text { HHDEBTL } \\
\geq \lambda\end{array}$ & $\lambda$ \\
\hline Switzerland & 126.3 & $\begin{array}{l}-0.03 \\
(0.02)\end{array}$ & $\begin{array}{c}0.00 \\
(0.03)\end{array}$ & 110.3 & $\begin{array}{l}-0.09 \\
(0.07)\end{array}$ & $\begin{array}{c}-0.14 \\
(0.03) *\end{array}$ & 110.6 \\
\hline $\begin{array}{l}\text { United } \\
\text { Kingdom }\end{array}$ & 82.3 & $\begin{array}{c}0.08 \\
(0.06)\end{array}$ & $\begin{array}{c}0.03 \\
(0.02)\end{array}$ & 34.2 & $\begin{array}{l}-1.88 \\
(0.10)^{*}\end{array}$ & $\begin{array}{l}-0.06 \\
(0.04)^{*}\end{array}$ & 34.2 \\
\hline Portugal & 72.41 & $\begin{array}{c}0.07 \\
(0.01)^{*}\end{array}$ & $\begin{array}{l}0.03 \\
(0.02)\end{array}$ & 58.8 & $\begin{array}{l}-1.59 \\
(0.19)^{*}\end{array}$ & $\begin{array}{l}-0.06 \\
(0.02)^{*}\end{array}$ & 25.1 \\
\hline Finland & 67.1 & $\begin{array}{l}-0.00 \\
(0.00)\end{array}$ & $\begin{array}{l}-0.03 \\
(0.05)\end{array}$ & 42.3 & $\begin{array}{l}-0.18 \\
(0.09)^{*}\end{array}$ & $\begin{array}{l}-0.02 \\
(0.04)\end{array}$ & 38.1 \\
\hline Spain & 64.1 & $\begin{array}{l}0.05 \\
(0.04)\end{array}$ & $\begin{array}{l}-0.01 \\
(0.02)\end{array}$ & 70.5 & $\begin{array}{l}-0.23 \\
(0.08)^{*}\end{array}$ & $\begin{array}{l}-0.15 \\
(0.03)^{*}\end{array}$ & 51.1 \\
\hline Australia & 122.3 & $\begin{array}{c}0.03 \\
(0.03)\end{array}$ & $\begin{array}{l}-0.00 \\
(0.00)\end{array}$ & 81.4 & - & - & - \\
\hline Sweden & 85.1 & $\begin{array}{c}0.05 \\
(0.02)^{*}\end{array}$ & $\begin{array}{c}0.03 \\
(0.10)\end{array}$ & 48.0 & - & - & - \\
\hline Greece & 60.8 & $\begin{array}{l}0.02 \\
(0.02)\end{array}$ & $\begin{array}{l}-0.21 \\
(0.13)^{*}\end{array}$ & 45.2 & - & - & - \\
\hline Germany & 53.2 & $\begin{array}{c}0.13 \\
(0.02)^{*}\end{array}$ & $\begin{array}{c}0.00 \\
(0.02)\end{array}$ & 50.8 & - & - & - \\
\hline
\end{tabular}




\begin{tabular}{|c|c|c|c|c|c|c|c|}
\hline Ireland & 52.3 & $\begin{array}{l}-0.02 \\
(0.09)\end{array}$ & $\begin{array}{c}0.24 \\
(0.08)^{*}\end{array}$ & 81.4 & - & - & - \\
\hline Norway & 101.2 & - & - & - & $\begin{array}{c}0.46 \\
(0.12)^{*}\end{array}$ & $\begin{array}{l}-0.00 \\
(0.03)\end{array}$ & 67.9 \\
\hline New Zealand & 92.4 & - & - & - & $\begin{array}{l}-0.16 \\
(0.13)\end{array}$ & $\begin{array}{c}-0.13 \\
(0.03)^{*}\end{array}$ & 61.9 \\
\hline France & 57.3 & - & - & - & $\begin{array}{c}0.21 \\
(0.05)^{*}\end{array}$ & $\begin{array}{c}-0.17 \\
(0.07)^{*}\end{array}$ & 32.5 \\
\hline
\end{tabular}

$\overline{\text { Notes: } * \text { and } * * \text { denotes significance at the } 5 \text { and } 10 \text { percent levels respectively. Values in parentheses are standard errors. } \lambda}$ represents the threshold estimate.

As such, based on the results, it shows that there is no consensus emerged on one "magic" threshold to apply for all countries. In addition, most of the countries in the sample are skewed towards the negative effect of debt on economic growth. By employing the endogenous Chow-structural test by Diallo (2012), Table 4 shows the breakpoints period. Based on the household debt growth and lagged household debt to GDP ratio, it shows that 2008, 2009 and 2010 were among the periods that have affected most of the countries (namely Korea, Sweden, Thailand, Hong Kong, Belgium, Singapore and France) which can be related to the United States sub-prime mortgage crisis. In addition, Korea was affected in 1999, which could possible due to 1998-1999 Asian Financial Crisis.

Table 4: Breakpoints for structural break

\begin{tabular}{ccccc}
\hline \hline Country & \multicolumn{2}{c}{ HHDEBT: household debt growth } & \multicolumn{2}{c}{$\begin{array}{c}\text { HHDEBT: Lagged household debt to } \\
\text { GDP ratio }\end{array}$} \\
& $\begin{array}{c}\text { Breakpoints detect } \\
\text { by Chow test (Year) }\end{array}$ & P-value & $\begin{array}{c}\text { Breakpoints detect } \\
\text { by Chow test (Year) }\end{array}$ & P-value \\
\hline Switzerland & $-*$ & $*$ & $*$ & $*$ \\
Australia & 1983 & 0.07 & - & - \\
Denmark & - & - & - & - \\
Netherland & - & - & - & - \\
Norway & - & - & - & - \\
Canada & - & - & - & - \\
Korea & 1999 & 0.03 & 2010 & 0.01 \\
New Zealand & - & & - & - \\
United Kingdom & 2000 & 0.03 & - & - \\
Sweden & 2009 & 0.02 & 1986 & 0.08 \\
Thailand & 2010 & - & - & - \\
United States & 2008 & - & 2009 & 0.01 \\
Portugal & - & - & - & - \\
Hong Kong & - & - & 2010 & 0.01 \\
Finland & 1990 & 0.09 & - & - \\
Luxembourg & $*$ & $*$ & - & $*$ \\
Spain & 2004 & 0.06 & 2000 & - \\
Greece & 2007 & 0.01 & 2010 & 0.09 \\
Belgium & 2003 & 0.10 & 2008 & 0.02 \\
Singapore & - & - & 2010 & 0.04 \\
France & - & - & - & 0.02 \\
Germany & - & - & 2002 & - \\
Ireland & - & - & - & - \\
Austria & - & -05 & - \\
\hline \hline
\end{tabular}

Notes: The Chow test is performed based on 'suchowtest' by Diallo (2012) and Berthelemy and Varoudakis (1996).

$*$ denotes that the breakpoint could not be estimated due to insufficient no of observations. 
By taking into account the estimated breakpoints, we re-estimate the baseline regression and the results are in Table 5 . We re-estimate results in Table 2 by considering country with breakpoint only. The segregation is based on the pre- and post-structural breakpoint periods. The results show that the null of linearity can be rejected for the household debt effect on economic growth in Australia, United Kingdom, Finland and France. This is consistent with the previous findings, implies that the non-linear relationship of the estimated model holds even with consideration of structural break point. With find new evidence of non-linear relationship between household debt and country's economic growth for Korea and Hong Kong.

Table 5: Re-estimating the nonlinear relationship between household debt and economic growth by considering the structural break points

\begin{tabular}{|c|c|c|c|}
\hline \multirow[t]{2}{*}{ Country } & \multirow[t]{2}{*}{ Sub-period } & \multicolumn{2}{|c|}{ LM test (White corrected) } \\
\hline & & $\begin{array}{l}\text { HHDEBT: household debt } \\
\text { growth }\end{array}$ & $\begin{array}{c}\text { HHDEBT: Lagged } \\
\text { household debt to GDP ratio }\end{array}$ \\
\hline \multirow[t]{2}{*}{ Australia } & $1978-1982$ & $72.9(0.63)$ & - \\
\hline & $1984-2016$ & $14.54(0.01)$ & - \\
\hline \multirow[t]{2}{*}{ Korea } & $1969-1998$ & $8.37(0.38)$ & $11.19(0.08)$ \\
\hline & $2000-2016$ & $7.32(0.51)$ & $3.89(0.82)$ \\
\hline \multirow[t]{2}{*}{ United Kingdom } & $1969-1998$ & $9.71(0.14)$ & - \\
\hline & 2001-2016 & $10.84(0.04)$ & - \\
\hline \multirow[t]{2}{*}{ Sweden } & $1981-2008$ & $10.14(0.11)$ & $1.92(0.40)$ \\
\hline & 2010-2016 & $3.52(0.56)$ & $7.75(0.47)$ \\
\hline \multirow[t]{2}{*}{ Thailand } & 1992-2009 & $9.01(0.23)$ & - \\
\hline & 2011-2016 & $2.74(0.36)$ & - \\
\hline \multirow[t]{2}{*}{ United States } & $1968-2007$ & $9.78(0.20)$ & $9.62(0.23)$ \\
\hline & 2009-2016 & $405(0.60)$ & $4.87(0.16)$ \\
\hline \multirow[t]{2}{*}{ Hong Kong } & 1991-2008 & - & $9.576(0.04)$ \\
\hline & $2010-2016$ & - & $3.93(0.36)$ \\
\hline \multirow[t]{2}{*}{ Finland } & 1971-1989 & $10.65(0.03)$ & - \\
\hline & 1991-2016 & $11.77(0.01)$ & - \\
\hline \multirow[t]{2}{*}{ Spain } & $1981-2003$ & $5.95(0.82)$ & - \\
\hline & $2005-2016$ & $6.37(0.53)$ & - \\
\hline \multirow[t]{2}{*}{ Greece } & $1995-2006$ & $5.35(0.76)$ & - \\
\hline & $2008-2016$ & $4.78(0.41)$ & - \\
\hline \multirow[t]{2}{*}{ Belgium } & $1981-2002$ & $8.96(0.19)$ & $9.40(0.23)$ \\
\hline & 2004-2016 & $7.99(0.18)$ & $1.96(0.57)$ \\
\hline \multirow[t]{2}{*}{ Singapore } & $1992-2007$ & - & $6.68(0.65)$ \\
\hline & 2009-2016 & - & $3.92(0.73)$ \\
\hline \multirow[t]{2}{*}{ France } & 1978-2009 & - & $11.16(0.06)$ \\
\hline & 2011-2016 & - & $2.17(0.10)$ \\
\hline \multirow[t]{2}{*}{ Austria } & $1996-2001$ & - & $2.57(0.93)$ \\
\hline & $2003-2016$ & - & $8.86(0.14)$ \\
\hline
\end{tabular}

Notes: $*$ and $* *$ denotes significance at the 5 and 10 percent levels respectively. Values in parentheses are p-values.

Table 6 shows that there is evidence of a turning points or optimal level of household debt for France, where the effect of household debt is positive below the threshold level of 32.9 percent. Above the threshold level, the effect of household debt becomes negative to affect country economic growth. This implies that the threshold estimates should be treated as a tipping point for France. In addition, the estimated threshold is 32.9 percent, which is slightly similar to the earlier estimate, which is 32.5 percent. Thus, this can treat as a tipping-point for France. While, Korea is 
experiencing the negative effect of household debt on country growth below and above the threshold level which indicates that the relationship is monotonic. Intuitively, holding debt more than the optimal level would poses a risk to the economy in the case of crisis. Any shock happens in the economy due to crisis or pandemic would lead to the possible issue of unemployment (income shock) which then affect the household ability to repay debt to the financial institutions. Furthermore, default cases in an economy of high level of aggregate household debt would danger the stability of the financial sector as in the 2008 United States sub-prime mortgage.

Table 6: Re-estimating the nonlinear effect of growth of household debt on country growth (using household debt as percentage of GDP as threshold variable)

\begin{tabular}{|c|c|c|c|c|c|c|c|}
\hline \multirow[t]{2}{*}{ Country } & \multirow[t]{2}{*}{ Period } & \multicolumn{3}{|c|}{$\begin{array}{l}\text { Growth rate of household debt on } \\
\text { economic growth }\end{array}$} & \multicolumn{3}{|c|}{$\begin{array}{l}\text { Lagged household debt to GDP } \\
\text { ratio effect on economic growth }\end{array}$} \\
\hline & & $\begin{array}{l}\text { HHDEBTL } \\
\leq \lambda\end{array}$ & $\begin{array}{l}\text { HHDEBTL } \\
\geq \lambda\end{array}$ & $\lambda$ & $\begin{array}{l}\text { HHDEBTL } \\
\leq \lambda\end{array}$ & $\begin{array}{l}\text { HHDEBTL } \\
\geq \lambda\end{array}$ & $\lambda$ \\
\hline Australia & $\begin{array}{l}1984- \\
2016\end{array}$ & $0.04 *(0.02)$ & $-0.00(0.00)$ & 81.38 & & & \\
\hline Korea & $\begin{array}{c}1969- \\
1998\end{array}$ & & & & $-3.70 *(0.74)$ & $-0.22 *(0.07)$ & 23.10 \\
\hline $\begin{array}{l}\text { United } \\
\text { Kingdom }\end{array}$ & $\begin{array}{l}2001- \\
2016\end{array}$ & $0.01(0.02)$ & $0.05 *(0.02)$ & 85.82 & & & \\
\hline $\begin{array}{l}\text { Hong } \\
\text { Kong }\end{array}$ & $\begin{array}{l}1991- \\
2008\end{array}$ & & & & $0.25 *(0.03)$ & $1.13(0.20)$ & 55 \\
\hline \multirow[t]{2}{*}{ Finland } & $\begin{array}{l}1971- \\
1989\end{array}$ & $0.02 *(0.01)$ & $0.03(0.03)$ & 24 & & & \\
\hline & $\begin{array}{l}1991- \\
2016\end{array}$ & $0.01(0.03)$ & $-0.02 *(0.12)$ & 41.3 & & & \\
\hline France & $\begin{array}{l}1978- \\
2009\end{array}$ & & & & $0.20 *(0.05)$ & $-0.18 *(0.05)$ & 32.9 \\
\hline
\end{tabular}

Notes: * and $* *$ denotes significance at the 5 and 10 percent levels respectively. Values in parentheses are standard errors. $\lambda$ represents the threshold estimate.

\section{CONCLUSION}

This paper aims to investigate household debt-growth nexus in countries with debt to GDP ratio exceeding 50 percent on the prediction of a threshold level. We have much to gain by considering findings of nonlinear effects of household debt on economic growth in some countries. In particular, we have two findings. First, the threshold estimates should not be considered a tipping point since the debt-growth nexus is a monotonically decreasing function, which implies the negative effect of household debt on economic growth. Second, the effect of debt on growth and threshold estimates are sensitive to different debt measurements and break points, thus it should be interpreted with caution. With a high level of debt holding, debt becomes fictitious which would expose countries to high risk of macroeconomic and financial stability. However, to date, there is no specific debt classification on how high is high. As the effect of household debt is negative, any income shock due to economic or pandemic issue would affect the household balance sheet badly. This evidence implies that with current high level of debt, policy maker should formulate policy to end household 'addiction' to debt. Future studies could be expanded towards analyzing the 
effect of household debt on income inequality, thus complementing the literature on the impact of financialization in the economy.

\section{REFERENCES}

Ando, A., \& Modigliani, F. (1963). The "life cycle" hypothesis of saving: Aggregate implications and Tests. The American Economic Review, 53, 55-84.

Alter, A., Feng, A. X., \& Valckx, N. (2018). Understanding the Macro-Financial Effects of Household Debt: A Global Perspective. IMF Working Paper WP/18/76.

Benhabib, J., \& Spiegel, M. (2000). The Role of Financial Development in Growth and Investment. Journal of Economic Growth, 5, 341-360.

Berthelemy, J. C., \& Varoudakis, A. (1996). Economic Growth, Convergence Clubs, and the Role of Financial Development. Oxford Economic Papers, 48, 300-328.

Chen, S., \& Kang, J. S. (2018). Credit Booms: Is China Different? IMF Working Paper WP/18/2.

Christopoulos, D., \& Tsionas, M. (2004). Financial Development an Economic Growth: Evidence from Panel Unit Root and Cointegration Tests. Journal of Development Economics, 73, $55-74$.

Cooper, D. (2012). Household Deleveraging: What Do the Aggregate and Household-Level Data Tell Us? Reserve Bank of Boston Public Policy Brief No. 12-2.

Daud, S. N. M., Ahmad, A. H., \& Podivinsky, J. (2017). Credit and the Housing Boom in Malaysia: A Comeback? Economics and Business Letters, 6, 110-115.

Daud, S. N. M., \& Podivinsky, J. (2011). An accumulation of international reserves and external debt: evidence from developing countries. Global Economic Review, 40, 229-249.

Daud, S. N. M., \& Podivinsky, J. (2014). Government debt and economic growth in Malaysia: the role of institutional quality. Applied Economics Letters, 21, 1179-1183.

Diallo, I. (2012). Suchowtest: Stata module to calculate successive chow tests on cross section data and time series data. Statistical Software Components S457536, Boston College Department of Economics.

Dynan, K. (2012). Is a Household Debt Overhang Holding Back Consumption? Brookings Papers on Economic Activity, 43(1), 299-362.

Dynan, K., \& Edelberg, W. (2013). The Relationship Between Leverage and Household Spending Behavior: Evidence from the 2007-2009 Survey of Consumer Finances. Federal Reserve Bank of St. Louis, 95(5), 425-448.

Fielding, D., \& Rewilak, J. (2015). Credit booms, financial fragility and banking crises. Economic Letters, 136, 233-236.

Friedline, T., \& Song, H. A. (2013). Accumulating assets, debts in young adulthood: Children as potential future investors. Children and Youth Services Review, 35, 1486-1502.

Friedman, M. (1957). A theory of the consumption function. Princeton: Princeton University Press.

Hansen, B. E. (2000). Sample splitting and threshold estimation. Econometrica, 68, 575-603.

Hassan, K., Sanchez, B., \& Yu, J. (2011). Financial development and economic growth: New Evidence from Panel Data. The Quarterly Review of Economics and Finance, 51, 88-108.

IMF. (2017). Global Financial Stability Report: Is Growth at Risk? Washington DC: International Monetary Fund.

Jappelli, T., Pagano, M., \& Di Maggio, M. (2013). Households' indebtedness and financial fragility. Journal of Financial Management, Markets and Institutions, 1, 23-46. 
Jorda, O., Schularick, M., \& Taylor, A.M (2013). When Credit Bites Back. Journal of Money, Credit and Banking, 45, 3-28.

Jorda, O., Schularick, M., \& Taylor, A. M. (2016). The Great Mortgaging: Housing Finance, Crises and Business Cycles, Economic Policy, 31, 107-152

Law, S. H., \& Singh, N. (2014). Does too much finance harm economic growth? Journal of Banking and Finance, 41, 36-44.

Law, S. H., Azman-Saini, W. N. W., \& Ibrahim, M. H. (2013). Institutional Quality Thresholds and the Finance - Growth Nexus. Journal of Banking and Finance, 37, 5373-5381.

Levine, R. (1997). Financial development and economic growth: Views and agenda. Journal of Economic Literature, 35, 688-726.

Levine, R. (2005). Financial and growth: Theory and evidence. In P. Aghion, \& S. N. Durlauf (Eds.), Handbook of Economic Growth. (pp. 865-937). Elsevier B.V.

Liang, Q., \& Teng, J-Z. (2006). Financial development and economic growth: Evidence from China. China Economic Review, 17, 395-411.

Lombardi, M., Mohanty, M., \& Shim, I. (2017). The real effects of household debt in the short and long run. BIS Working Papers No 607. Basel: Bank of International Settlement.

Mian, A., \& Sufi, A. (2009). The consequences of mortgage credit expansion: Evidence from the US mortgage default crisis. The Quarterly Journal of Economics, 124, 1449-1496.

Mian, A., \& Sufi, A. (2010). Household Leverage and the Recession of 2007-2009. IMF Economic Review, 58, $74-117$.

Mian, A., \& Sufi, A. (2011). House Prices, Home Equity-Based Borrowing, and the U.S. Household Leverage Crisis. American Economic Review, 101, 2132-2156.

Mian, A., Rao, K., \& Sufi, A. (2013). Household Balance Sheets, Consumption, and the Economic Slump. Quarterly Journal of Economics, 128, 1687-1726.

Mian, A, Sufi, A., \& Emil, V. (2017). Household Debt and Business Cycles Worldwide. Quarterly Journal of Economics, 132, 1755-1817.

Mian, A., Sufi, A., \& Verner, E. (2015). Household Debt and Business Cycle Worldwide. NBER Working Paper No. 21581. Cambridge, Ma: National Bureau of Economic Research.

Mishkin, F. (1978). The household balance sheet and the Great Depression. The Journal of Economic History, 38, 918-937.

Nakajima, J. (2020). The role of household debt heterogeneity on consumption: Evidence from Japanese household data. Economic Analysis and Policy, 65, 186-197.

Ntsalaze, L., \& Ikhide, S. (2017). The Threshold Effects of Household Indebtedness on Multimensional Poverty. International Journal of Social Economics, 44, 1471-1488.

Rubaszek, M., \& Serwa, D. (2014). Determinants of credit to households: an approach using the life-cycle model. Economic System, 38, 572-587.

Schularick, M., \& Taylor, A.M. (2012). Credit Booms Gone Bust: Monetary Policy, Leverage Cycles, and Financial Crises, 1870-2008. American Economic Review, 102, 1029-1061. 
Appendix 1: Data descriptions

\begin{tabular}{|c|c|c|}
\hline Variables & Definition & Data sources \\
\hline $\begin{array}{l}\text { Growth rate of GDP } \\
\text { per capita }\end{array}$ & Annual percentage growth rate & $\begin{array}{c}\text { World Development Indicator (WDI) from } \\
\text { the World Bank (WB) }\end{array}$ \\
\hline Initial income & $\begin{array}{l}\text { Lagged levels of GDP per capita in constant } \\
2010 \text { U.S. dollars (in natural log) }\end{array}$ & $\begin{array}{c}\text { World Development Indicator (WDI) from } \\
\text { the World Bank (WB) }\end{array}$ \\
\hline Investment & $\begin{array}{c}\text { Gross capital formation as percentage of } \\
\text { GDP }\end{array}$ & $\begin{array}{c}\text { World Development Indicator (WDI) from } \\
\text { the World Bank (WB) }\end{array}$ \\
\hline Population growth & Annual growth (in percent) & $\begin{array}{c}\text { World Development Indicator (WDI) from } \\
\text { the World Bank (WB) }\end{array}$ \\
\hline Trade & $\begin{array}{l}\text { Total exports plus imports as percentage of } \\
\text { GDP }\end{array}$ & $\begin{array}{c}\text { World Development Indicator (WDI) from } \\
\text { the World Bank (WB) }\end{array}$ \\
\hline Household debt & Total household debt as percentage of GDP & Bank of International Settlement and IMF \\
\hline
\end{tabular}

